\title{
Commentary: The changing face of risk management
}

\author{
Heather K. Hayanga, MD, MPH, ${ }^{\mathrm{a}}$ Ankit Dhamija, MD, ${ }^{\mathrm{b}}$ and J. W. Awori Hayanga, MD, MPH ${ }^{\mathrm{b}}$
}

\author{
From the ${ }^{\mathrm{a}}$ Division of Cardiac Anesthesia, WVU Heart and Vascular Institute, and ${ }^{\mathrm{b}}$ Department of Cardiovascular \\ and Thoracic Surgery, West Virginia University, Morgantown, WVa. \\ Disclosures: Authors have nothing to disclose with regard to commercial support. \\ Received for publication Oct 7, 2019; revisions received Oct 7, 2019; accepted for publication Oct 7, 2019; \\ available ahead of print Oct 24, 2019. \\ Address for reprints: J.W. Awori Hayanga, MD, MPH, West Virginia University School of Medicine, 1 Medical \\ Center Dr, Morgantown, WV 26505-8059 (E-mail: jeremiah.hayanga@wvumedicine.org). \\ J Thorac Cardiovasc Surg 2020;160:582 \\ $0022-5223 / \$ 36.00$ \\ Copyright (c) 2019 by The American Association for Thoracic Surgery \\ https://doi.org/10.1016/j.jtcvs.2019.10.044
}

In this issue of the Journal, Lehr and colleagues ${ }^{1}$ have submitted an analysis of national data from the Scientific Registry and Transplant Recipients database pertaining to lung transplantations performed between 2006 and 2017. The authors proffer an analysis against a backdrop of highvolume transplantation and prerequisite experience in the field. To this end, they adjudicated recipient outcomes dichotomized by having received either "high"- or "increased"-risk organs, predicated on a recent switch in nomenclature by the US Public Health Service that recently took effect. ${ }^{2}$

The manuscript is timely and relevant as the transplant community grapples with a global paucity of donors and an increasingly compelling need to demystify and destigmatize "high-risk" donation to keep pace with demand(s) for organs. The piece is of substantial political import, particularly in the context of organ donation in an era of a devastating national opioid epidemic juxtaposed against an increasing incidence of intravenous drug abuse. These unfortunate events have culminated in establishing drug overdose as the major rival to trauma as the leading cause of death in people younger than 40 years and estimated at a staggering 57 per 100,000 in West Virginia. ${ }^{3}$ As such, the work builds on a growing body of evidence. ${ }^{4,5}$

A glaring omission in this analysis, however, is the lack of a more specific, nuanced, definition of acute rejection. The tacit assumption that treatment of this rejection, within 1-year post-transplantation, qualifies as an objective secondary outcome may inadvertently result in the observation of a $100 \%$ event rate. Indeed, mild acute rejection is, arguably, a subjectively common, even ubiquitous, occurrence, somewhat underscoring the limitation inherent in an explicit assessment of rejection as a binary event rather than as a continuum. The clinical management and documentation are, in this vein, left to the discretion of the treating physician and, as such, are rife with subjective interobserver variability. The latter influences the estimation of both survival and rejection. Use of propensity matching notwithstanding, objective quantification of the risk of a whole.

\section{References}

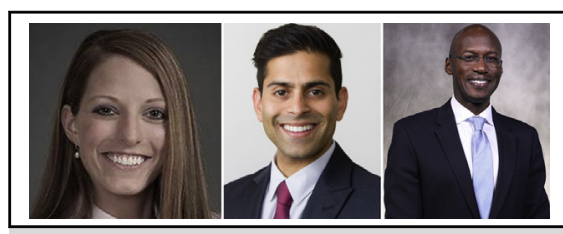

Heather K. Hayanga, MD, MPH, Ankit Dhamija, MD, and J. W. Awori Hayanga, MD, MPH

Central Message

Using organs from increased-risk donors does not jeopardize outcomes.

See Article page 572.

transmission, replete with long-term surveillance, would have likely proffered a more persuasive treatise. Furthermore, this may have prompted a more elaborate quantification of the actual threat posed by a positive nucleic acid test screen as it specifically pertains to communicable disease and bloodborne pathogens in the transplant population as

On an objective note, the low transmission rate lends further credence to the impetus to destigmatize the risk attributed to these donors. Contemporary patterns of use of intravenous drugs suggest that the numbers of "increased-risk" donors will continue to grow in the future. Despite the apparent controversy in optics, however, it is finally incumbent on the transplant community to alter views, moderate preconceived biases, and temper prejudice in this regard. In the absence of an entirely new mindset to accompany the new nomenclature, we will miss the opportunity to alleviate the catastrophic loss of precious young donors by the salvage of the equally precious lives of the growing number of candidates on the waitlist.

1. Lehr CJ, Lopez R, Arrigain S, Schold J, Koval C, Valapour M. The impact of change in definition of increased-risk donors on survival after lung transplantation. J Thorac Cardiovasc Surg. 2020;160:572-81.

2. Sapiano MRP, Jones JM, Bowman J, Levi ME, Basavaraju SV. Impact of US Public Health Service increased risk deceased donor designation on organ utilization. Am J Transplant. 2019;19:2560-9.

3. Centers for Disease Control and Prevention. Stats of the State of West Virginia. Available at: https://www.cdc.gov/nchs/pressroom/states/westvirginia/west virginia.htm. Accessed October 5, 2019.

4. Bansal S, Hayanga J, Odell J, Odell D, Jeong K, Fabio A, et al. Risky business: taking the stigma out of high-risk donation in lung transplantation. Ann Thorac Surg. 2015;100:1787-93; discussion 1793-4.

5. Gaffey AC, Doll SL, Thomasson AM, Venkataraman C, Chen CW, Goldberg LR, et al. Transplantation of "high-risk" donor hearts: implications for infection. J Thorac Cardiovasc Surg. 2016;152:213-20. 